\title{
PERSPEKTIF
}

Available online http://ojs.uma.ac.id/index.php/perspektif

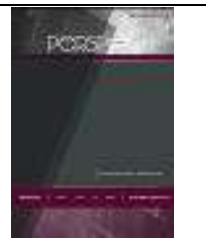

\section{Faktor-Faktor yang Mempengaruhi Keterlambatan Rekapitulasi Penghitungan Suara pada Pemilu Tahun 2019}

\section{Factors Affecting the Delay in Recapitulation of Vote Counting in the 2019 Election}

\author{
Dana Permana, M. Arif Nasution \& Arifin Saleh Siregar \\ Program Studi Magister Ilmu Politik, Fakultas Ilmu Sosial Dan Ilmu Politik, Universitas \\ Sumatera Utara, Indonesia
}

Diterima: 05 Agustus 2020; Disetujui: 15 Desember 2020; Diterbitkan: 31 Januari 2021.

\begin{abstract}
Abstrak
Keterlambatan rekapitulasi penghitungan suara di Kabupaten Deli Serdang pada Penyelenggaraan Pemilu tahun 2019 menyebabkan tergangunnya proses pada tahapan penyelenggaraan pemilu di tingkat Provinsi Sumatera Utara, meski berdasarkan tahapan Pemilu 2019 keterlambatan tersebut tidak mengganggu proses rekapitulasi nasional. Tetapi dalam skala regional dan lokal dapat mengakibatkan ketidakpercayaan publik pada kinerja dan integritas KPU dan pada akhirnya dapat memicu munculnya konflik berskala lokal diantara peserta Pemilu yang sama-sama harap-harap cemas menanti hasil penghitungan suara. Dari hasil penelitian yang penulis lakukan untuk melihat peristiwa keterlambatan rekapitulasi penghitungan suara di Kabupaten Deli Serdang pada Pemilu 2019 yang lalu. Penulis menggunakan asumsi untuk menguji bahwa keterlambatan tersebut disebabkan oleh 3 faktor yakni faktor integritas penyelenggara pemilu, faktor beban kerja dan faktor kompetensi penyelenggara pemilu. Kata Kunci: Faktor-Faktor Yang Mempengaruhi; Keterlambatan; Rekapitulasi Penghitungan Suara
\end{abstract}

\begin{abstract}
The delay in recapitulation of vote counts in Deli Serdang Regency during the 2019 Election caused disruption to the process at the stage of election implementation at the North Sumatra Province level, even though based on the 2019 Election stages the delay did not interfere with the national recapitulation process. However, on a regional and local scale this can lead to public distrust of the performance and integrity of the KPU and in the end it can lead to the emergence of local scale conflicts among election participants who are both anxiously awaiting the vote count results. From the results of the research that the author conducted to see the delay in recapitulation of vote counts in Deli Serdang Regency in the last 2019 Election. The author uses the assumption to test that the delay is caused by 3 factors, namely the election organizer integrity factor, the workload factor and the election organizer competency factor. Keywords: Affecting Factors; Delay; Recapitulation of Vote Counting
\end{abstract}

How to Cite: Permana, D. Nasution, M.A., \& Siregar, A.S., (2021). Analisis Faktor-Faktor Yang Mempengaruhi Keterlambatan Rekapitulasi Penghitungan Suara pada Pemilu Tahun 2019. PERSPEKTIF, 10 (1): 100-109.

*Corresponding author: ISSN 2085-0328 (Print)

E-mail: danapermana@gmail.com ISSN 2541-5913 (online) 


\section{PENDAHULUAN}

Pelaksanaan pemilihan umum (Pemilu) di negara-negara dengan iklim demokrasi yang stabil dan sudah berpengalaman melaksanakan pemilu tidak selamanya bebas dari berbagai gangguan atau hambatan. Meskipun bagi penganut demokrasi keberadaan (eksistensi) Pemilu dianggap sebagai sebuah realisasi kedaulatan rakyat (people souvereignity) serta merupakan sarana memperkuat legitimasi rakyat (people legitimation) terhadap Negara yang pada akhirnya Pemilu diharapkan dapat tampil sempurna tanpa cacat (Haris, 1998).

Bagaimana idealnya sebuah Pemilu dikatakan sempurna atau demokratis itu. Bagi Dahl misalnya pemilu dikatakan sukses jika dilaksanakan secara bebas dengan minimalisir praktek-praktek kekerasan yang kemudian ditafsirkan oleh Gaffar (2000) sebagai pemilu dengan adanya kebebasan kepada mereka yang sudah dewasa menggunakan hak konstitusionalnya yakni memilih dan dipilih dengan leluasa tanpa paksaan atau intimidasi dari pihak manapun sehingga pada akhirnya bisa memilih sesuai hati nurani (Gaffar, 2000).

Dalam frekuensi yang sama membincangkan Pemilu yang demokratis, Macridis (1989) memberikan 8 persyaratan untuk memberikan pengakuan terhadap pemilu yang demokratis. Salah satunya adalah perhitungan suara yang jujur di samping adanya pengakuan hak pilih universal, pluralisme (pluralism), mekanisme rekruitmen politik (political recruitment mechanism), kebebasan menentukan pilihan (freedom of voting), ada komite atau panitia independen pemilihan, keleluasaan berkompetesi dan netralitas birokrasi (bureaucracy neutrality) (Magridis dan Huliung, 1997).

Pentingnya pelaksanaan pemilu yang demokratis menjadi satu syarat dalam menghitung kadar sebuah sistem politik sudah demokratis atau melenceng dari nilai-nilai demokrasi (Fatah, 1997). Selain itu tujuan yang terpenting juga menjaga agar pemilu tidak sebatas dijadikan sebagai sarana ritualitas belaka (ajang 5 tahunan). Pada titik itulah maka diperlukan standar bagaimana pemilu yang berlangsung menjadi ajang yang partisipatif, terbuka, jujur dan adil sebagai konsekuensi nilai-nilai demokrasi.

Indonesia sebagai sebuah Negara demokrasi sudah beberapa kali melaksanakan Pemilu dimulai pertama sekali pada tahun
1955 sebagai Pemilu pertama dan terakhir pada masa rezim orde lama dibawah kepemimpinan Presiden Sorkarno. Berikutnya pasa masa Rezim Orde Baru dibawah komando mendiang Presiden Soeharto sukses menyelenggarakan Pemilu sebanyak 6 kali masing-masing pada tahun 1971, 1977, 1982, 1987, 1992, dan 1997. Era Reformasi setelah lengsernya Soeharto Pemilu digelar pada tahun 1999, 2004, 2009, 2014 dan 2019.

Tahun 2019 yang lalu Indonesia kembali melaksanakan Pemilihan Umum (Pemilu) untuk yang ke 12 kalinya sejak Pemilu pertama diadakan pada tahun 1955. Secara umum berbagai pihak baik dalam negeri maupun pemerhati dari luar negeri mengapresiasi pelaksanaan Pemilu 2019 berjalan dengan baik ditandai dengan adanya pergantian kekuasaan dengan cara damai. Lihat Pernyataan Wiranto 'Pelaksanaan Pemilu 2019 Dapat Banyak Apresiasi dari Luar Negeri dalamhttps://nasional.kompas.com/read/201 9/04/24/11252091/wiranto-pelaksanaanpemilu-2019-dapat-banyak-apresiasi-dariluar-negeri. Lihat juga pertanyaan dari Komnas HAM RI di https://mediaindonesia.com/read/detail/230 718-komnas-ham-apresiasi-pelaksanaanpemilu.Eksekutif dan legislatif memberikan apresiasi yang positif terhadap pelaksanaan pemilu 2019 lihatdihttps://www.pinterpolitik.com/jokowiapresiasi-pemilu-

2019/https://infojambi.com/dpd-ri-apresiasipemilu-2019-berjalan-aman-dan-damai/, https://kabar24.bisnis.com/read/20190417/ 15/913023/dpr-peninjau-asing-apresiasipemilu-serentak-tapi-damai

Namun dibalik apresiasi yang positif tersebut Pemilu 2019 tetap memiliki catatan yang perlu diperbaiki guna menghasilkan Pemilu yang lebih berkualitas. Beberapa catatan untuk menjadi perhatian seperti gugurnya para Penyelenggara Pemilu di tingkat KPPS, dugaan ketidaknetralan ASN, Hoax yang merajalela, kampanye di medsos, menguatnya politik identitas serta permasalahan klasik Pemilu lainnya (Masmulyadi, 2019).

Dari aspek penyelenggaraan Pemilu sendiri beberapa permasalahan menurut Badan Pengawas Pemilu (Bawaslu) RI terkait hak politik, kampanye, pungut hitung, rekapitulasi, penegakan hukum dan perselisihan hasil pemilu, dari penjelasan 
Bawaslu sebagai pengawas pemilu perihal evaluasi pemilu khususnya yang berkaitan dengan tahapan pemungutan dan penghitungan suara menjadi salah satu objek evaluasi yang harus disikapi dengan cermat.

Dalam setiap pelaksanaan Pemilu bukan saja di Indonesia, tahapan yang paling krusial dalam menentukan keberhasilan pemilu secara keseluruhan adalah tahap pemungutan dan penghitungan suara. Berbicara dalam konteks penyelenggaraan pemilu di Indonesia, umumnya permasalahan yang kemudian banyak diangkat dalam persidangan di Mahkamah Konstitusi tidak lain berkaitan dengan perselisihan hasil pemilu bermuara dari tahapan penghitungan suara.

Mengapa tahapan ini menjadi salah satu isu yang krusial. Hal ini disebabkan banyak aspek seperti legitimasi (Legitimasi sebuah Pemilu dipengaruhi oleh hal seperti ketepatan waktu, inklusivitas dan lainnya (ACE Project), Integritas Pemilu atau Manajemen Pemilu. Bisa dibayangkan jika kemudian hasil Pemilu tidak memiliki legitimasi akan mengakibatkan ketidakstabilan politik yang pada akhirnya memengaruhi dimensi yang lain seperti ekonomi (economics), sosial hingga keamanan (social and security). Oleh sebab itu dalam konteks pemilu penghitungan suara menjadi salah satu prinsip fundamental untuk dilaksanakan dengan baik.

Dalam diskursus internasional akurasi dan ketepatan waktu adalah 2 (dua) hal dari beberapa prinsip yang utama menyangkut diskusi seputar penghitungan suara (vote counting) dari 8 prinsip pelaksanaan penghitungan suara yakni, transparansi, sekuriti, profesionalisme, akurasi, kerahasian, tepat waktu, akuntabel dan kesamaan. Karena Pemilu berbicara tentang membangun pemahaman dan kepercayaan publik termasuk peserta Pemilu (IDEA). Ketika keduanya dapat berjalan seiringan maka pemilu yang berlangsung memiliki legitimasi yang kuat namun sebaliknya hal tersebut bisa menjadi preseden buruk tidak saja terhadap pemilu namun berdampak pada pembangunan politik (political development).

Dalam konteks pelaksanaan Pemilu 2019 di Indonesia, persoalan rekapitulasi penghitungan suara masih menjadi salah satu kendala yang berpotensi mengganggu jalannya penyelenggaraan pemilu yang tepat waktu. Pelaksanaan rekapitulasi di sejumlah daerah mengalami keterlambatan dari jadwal yang ditetapkan oleh KPU. Daerah-daerah yang mengalami keterlambatan penyelesaian rekapitulasi dari waktu yang semestinya pada Pemilu 2019 yang lalu antara lain Riau, Maluku, Papua dan Provinsi Sumatera Utara (kpu.go.id).

Berikut adalah jadwal pelaksanaan rekapitulasi penghitungan suara pada penyelenggaraan pemilu tahun 2019 sesuai jadwal yang ada pada Peraturan KPU.

Tabel. 1. Jadwal Pelaksanaan Rekap Penghitungan Suara Pemilu 2019

\begin{tabular}{lll}
\hline No & $\begin{array}{l}\text { Rekapitulasi } \\
\text { Penghitungan Suara }\end{array}$ & $\begin{array}{l}\text { Jadwal } \\
\text { Pelaksanaan }\end{array}$ \\
\hline 1. & Tingkat KPPS & 17 s/d 18 April \\
\hline 2. & Tingkat PPK & 18 April s/d 4 Mei \\
\hline 3. & Tingkat & Kabupaten/Kota \\
& 20 April s/d 7 Mei \\
\hline 4. & Tingkat KPU Provinsi & $\begin{array}{l}\text { 22 April s/d 12 } \\
\text { Mei }\end{array}$ \\
\hline 5. & Tingkat Nasional KPU & $\begin{array}{l}\text { 25 April s/d 25 } \\
\text { Mei }\end{array}$ \\
\hline
\end{tabular}

Sumber. Peraturan Komisi Pemilihan Umum No 14 Tahun 2019

Dalam pelaksanaan Pemilu 2019 tahun baik Provinsi Riau, Maluku, Papua dan Provinsi Sumatera Utara melaksanakan rekapitulasi di tingkatan provinsi dan beberapa daerah melampaui jadwal tahapan pemilu. Sehingga alur pelaksanaan rekapitulasi yang dilaksanakan secara berjenjang yang bermuara di tingkat nasional mengalami gangguan yang dapat mengancam legitimasi hasil pemilu serta mengacaukan tatanan pemilu yang sudah dirumuskan sejak awal.

Dari ke 4 daerah tersebut, Provinsi Sumatera Utara menjadi daerah yang menjadi perhatian dari pimpinan KPU RI di Jakarta serta menjadi sorotan para pemangku kepentingan yang ada di tingkat pusat dan juga daerah. Dalam konteks keterlambatan penyelenggaraan proses rekapitulasi penghitungan suara di Sumatera Utara sama seperti daerah lainya mengalami keterlambatan disebabkan menunggu proses rekapitulasi tingkat KPU Kabupaten dan Kota.

Berdasarkan Laporan KPU Provinsi Sumatera Utara, Kabupaten yang mengalami keterlambatan yakni Kabupaten Deli Serdang dan Kabupaten Nias Selatan. Alasan Kabupaten Deli Serdang menyisakan proses rekapitulasi ditingkat Kecamatan, sedangkan keterlambatan di Kabupaten Nias Selatan disamping juga menindaklanjuti rekomendasi Bawaslu Provinsi Sumatera Utara perihal 
penyandingan dan penghitungan ulang rekap hasil penghitungan suara di Kabupaten Nias Selatan khususnya Kecamatan Toma sebanyak 3 TPS (Kompas 19 Mei 2019).

Kabupaten Deli Serdang sendiri menyelesaikan rapat pleno rekapitulasi penghitungan suara pada 18 mei 2019 setelah mengalami perpanjangan waktu dari tahapan yang sudah ditetapkan oleh KPU RI. Dinamika terkendalanya pleno rekapitulasi di Kabupaten Tabel 1.2

Waktu Penyelesaian Rekapitulasi Kecamatan Kabupaten Deli Serdang Pemilu 2019
Deli Serdang disebabkan oleh permasalahan rekapitulasi di beberapa kecamatan yang belum selesai (Medan Bisnis, 19 Mei 2019). Akibat keterlambatan rekap di tingkat kecamatan tersebut mengakibatkan terganggunya proses rekapitulasi di level atas yakni di level Kabupaten dan Provinsi. Untuk rincian penyelesaian waktu rekapitulasi penghitungan suara disajikan dalam tabel berikut.

\begin{tabular}{|c|c|c|c|c|}
\hline \multirow[t]{2}{*}{ No } & \multirow[t]{2}{*}{ Kecamatan } & \multirow[t]{2}{*}{$\begin{array}{l}\text { Penyelesaian } \\
\text { Rekapitulasi } \\
\end{array}$} & \multicolumn{2}{|c|}{$\begin{array}{l}\text { Akurasi } \\
\text { Rekapitulasi Tingkat TPS (Per Kelurahan/Desa) }\end{array}$} \\
\hline & & & Bersih & Bermasalah \\
\hline 1. & Bangun Purba & $4 \mathrm{Mei}$ & & \\
\hline 2. & Batang Kuis & $4 \mathrm{Mei}$ & & \\
\hline 3. & Beringin & $4 \mathrm{Mei}$ & & \\
\hline 4. & Biru-Biru & $4 \mathrm{Mei}$ & & \\
\hline 5. & Deli Tua & $4 \mathrm{Mei}$ & & \\
\hline 6. & Galang & 4 Mei & & \\
\hline 7. & Gunung Meriah & $4 \mathrm{Mei}$ & & \\
\hline 8. & Hamparan Perak & 4 Mei & & \\
\hline 9. & Kutalimbaru & 4 Mei & & \\
\hline 10. & Labuhan Deli & $4 \mathrm{Mei}$ & & \\
\hline 11. & Lubuk Pakam & $4 \mathrm{Mei}$ & & \\
\hline 12. & Namo Rambe & $4 \mathrm{Mei}$ & & \\
\hline 13. & Pagar Merbau & 4 Mei & & \\
\hline 14. & Pancur Batu & 4 Mei & & \\
\hline 15. & Pantai Labu & $4 \mathrm{Mei}$ & & \\
\hline 16. & Patumbak & $4 \mathrm{Mei}$ & & \\
\hline 17. & Percut Sei Tuan & $15 \mathrm{Mei}$ & 8 & 12 \\
\hline 18. & Sibolangit & $4 \mathrm{Mei}$ & & \\
\hline 19. & Sinembah Tj Muda Hilir & 4 Mei & & \\
\hline 20. & Sinembah Tj Muda Hulu & 4 Mei & & \\
\hline 21. & Sunggal & $12 \mathrm{Mei}$ & 10 & 7 \\
\hline 22. & Tanjung Morawa & 12 Mei & 8 & 18 \\
\hline
\end{tabular}

Sumber : KPU Kabupaten Deli Serdang (tahun 2020)

Dari tabel di atas dapat dilihat bahwa pada pelaksanaan rekapitulasi penghitungan suara di Kabupaten Deli Serdang di Pemilu 2019 terdapat 3 Kecamatan yang melakukan rekapitulasi melebihi tahapan atau jadwal yang sudah ditetapkan oleh KPU. Kecamatan dimaksud adalah Kecamatan Percut Sei Tuan, Kecamatan Tanjung Morawa dan Kecamatan Sunggal.

Kontribusi keterlambatan tahapan rekapitulasi penghitungan suara di beberapa daerah (baik Provinsi Riau, Maluku, Papua dan Provinsi Sumatera Utara) memaksa KPU RI kemudian mengeluarkan kebijakan tentang perpanjangan masa rapat rekapitulasi penghitungan suara di daerah.

Hal ini untuk mengantisipasi kemungkinan terburuk jika kemudian tidak ada payung hukum bagi KPU di daerah untuk tetap melaksanakan Rekapitulasi yang masih terus berlanjut meskipun memang tidak menggangu tahapan rekapitulasi di tingkat nasional. Sehingga kemudian jadwal rapat pleno rekapitulasi penghitungan suara menyesuaikan dengan adanya kebijakan dari KPU RI. Perubahan dalam bentuk penambahan waktu bagi daerah yang mengalami keterlambatan 
proses rekap penghitungan suara disajikan dalam tabel berikut:

Tabel. 3. Penyesuaian Jadwal Pleno Rekap Penghitungan Suara Pemilu 2019

\begin{tabular}{lllll} 
No & Rekapitulasi & PKPU & SE & Penambahan \\
& & $9 /$ & KPU & \\
& & 2019 & & \\
\hline 1. & PPK & 18 & 18 & 11 Hari \\
& & April & April & \\
& & s/d 4 & s/d & \\
& & Mei & 15 & \\
& & & Mei & \\
\hline 2. & Kab/Kota & 20 & 20 & 8 Hari \\
& & April & April & \\
& & s/d 7 & s/d & \\
& & Mei & 15 & \\
& & & Mei & \\
\hline 3. & Provinsi & 22 & 22 & 3 Hari \\
& & April & April & \\
& & s/d & s/d & \\
& & 12 & 15 & \\
& & Mei & Mei & \\
\hline
\end{tabular}

Sumber: Surat Edaran KPU No 812.PL.02.6$\mathrm{SD} / \mathrm{KPU} / \mathrm{V} / 2019$

Keterlambatan proses rekapitulasi penghitungan suara sendiri diakibatkan permasalahan akurasi yang bisa disebabkan oleh beragam faktor meminjam Norris, Birch bisa berkaitan dengan masalah integritas penyelenggara pemilu dan juga faktor lainnya yang bekaitan dengan kinerja penyelenggara Pemilu misal beban kerja (workload) dan faktor Kompetensi (competency).

Permasalahan integritas pemilu dalam meneropong persoalan kepemiluan seperti malpraktik pemilu menjadi perhatian banyak ahli bahkan sudah menjadi kesepakatan dunia internasional bahwa Pemilu yang berintegritas lah yang akan melahirkan Pemilu yang bebas dan adil.

Tidak bisa dipungkiri bahwa dalam pelaksanaan Pemilu peran dari penyelenggara Pemilu menjadi faktor yang sangat penting terlepas dari model pembentukannya (Model Pembentukan Penyelenggara Pemilu umumnya diklasifikasikan kepada tiga model yakni model Independen, Model Pemerintah dan Model Gabungan (Independen dan Pemerintah). serta faktor integritas Pemilu berkaitan dengan bagaimana penyelenggara Pemilu menjalankan pemilu yang berintegritas.

Namun kemudian jika integritas berkaitan dengan aspek etika dan moral yang juga diperlukan tentu juga aspek kemampuan (competency), kompetensi ini dimaknai sebagai kapasitas penyelenggara dalam melaksanakan tugasnya sebagai seorang penyelenggara pemilu.

Aspek berikutnya dalam melihat sebuah kegiatan berjalan selain dari aspek manusia (human) bisa dilihat juga dari aspek lingkungan diluar dari aspek human tadi. Dalam konteks ini aspek beban kerja (workload) dan juga dalam tataran manajemen organisasi adanya supervisi atau pengawasan menjadi alasan untuk menganalisis sebab terkendalanya sebuah aktivitas atau kegiatan dengan memadukan aspek humanitas dan aspek lingkungan maka dapat digambarkan secara komprehensif di aspek mana kemudian kegiatan rekapitulasi penghitungan suara di Kabupaten Deli Serdang mengalami keterlambatan.

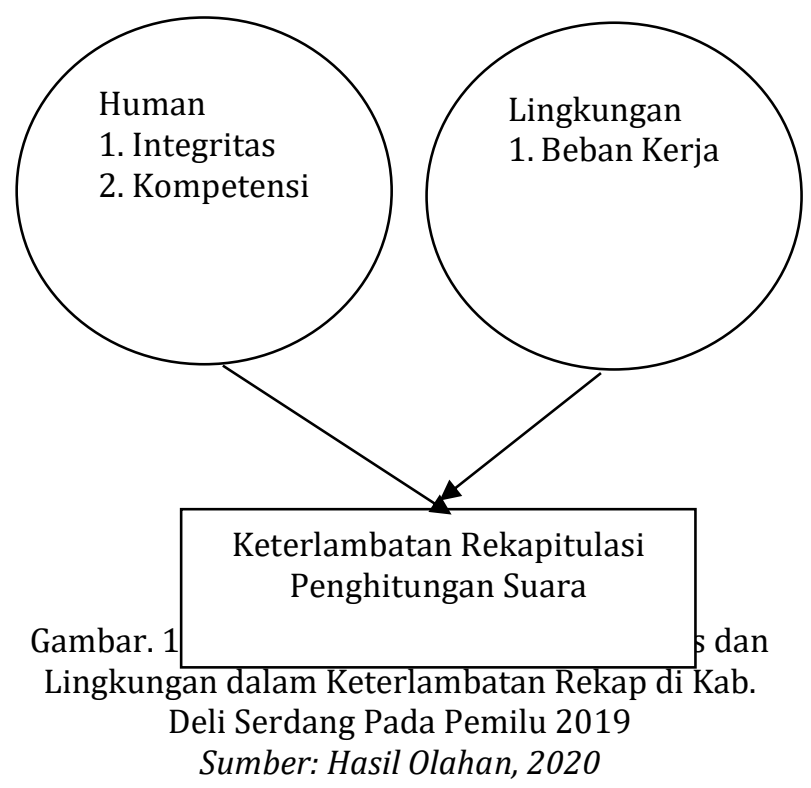

Fenomena keterlambatan proses rekapitulasi penghitungan suara di Kabupaten Deli Serdang menarik untuk diteliti dikarenakan dalam proses rekapitulasi yang sedang dilaksanakan oleh KPU RI yang akhirnya ditetapkan rekapitulasi perolehan suara pada pemilu 2019 pada 21 Juni 2019. Dinamika yang menyelimuti peristiwa tersebut salah satunya adalah menunggu proses rekapitulasi penghitungan suara yang dilakukan di Kabupaten Deli Serdang.

Dalam kaitannya dengan latar belakang diatas, penelitian ini berupaya untuk mengkonfirmasi apakah keterlambatan pelaksanaan rekapitulasi penghitungan suara di Kabupaten Deli Serdang pada Pemilu 2019 yang lalu disebabkan oleh faktor-faktor yakni integritas penyelenggara pemilu, beban kerja 
atau kompetensi penyelenggara pemilu baik secara parsial maupun bersamaan.

\section{METODE PENELITIAN}

Riset dikerjakan di daerah tingkat II, Deli Serdang Provinsi Sumatera Utara, tepatnya di 3 kecamatan yakni kecamatan Sunggal, kecamatan Tanjung Morawa dan Kecamatan Percut Sei Tuan. 3 kecamatan ini dipilih sebagai lokasi penelitian dikarenakan pada waktu pelaksanaan rekapitulasi penghitungan suara pada Pemilu 2019 yang lalu ke 3 nya mengalami keterlambatan proses rekap penghitungan suara.

Pendekatan yang dipilih yakni kuantitatif, alasan penulis mengambil pendekatan tersebut untuk dapat melihat dan mengukur faktorfaktor yang mempengaruhi terkendalanya rekapitulasi penghitungan suara secara tepat. Metode ini penulis anggap relevan untuk melihat korelasi (hubungan) dengan permasalahan penelitian yang akan dijawab dalam bentuk yang dapat dikuantifikasikan (Lisa, 2007).

Adapun yang menjadi populasi dalam penelitian ini adalah seluruh Panitia Pemilihan Kecamatan (PPK) yang ada di Kecamatan Sunggal, Kecamatan Tanjung Morawa dan Kecamatan Percut Sei Tuan Kabupaten Deli Serdang Provinsi Sumatera Utara sebanyak 15 orang dan 15 orang KPU Kabupaten Deli Serdang yang bertugas dalam kelompok kerja yang menangani dan bertanggungjawab terhadap pelaksanaan pemungutan dan rekapitulasi penghitungan suara di Kabupaten Deli Serdang pada Pemilu 2019. Sedangkan yang menjadi sampel menurut Arikunto (2010). Untuk keterangan lebih rinci tentang sampel dan juga populasi dari riset disajikan pada tabel berikut.

Tabel 3. Jumlah Populasi dan Sampel

\begin{tabular}{llll}
\hline No & Populasi (P) & & Sampel (n) \\
\hline 1 & PPK Sunggal & 5 & 0 \\
\hline 2 & PPK Tanjung Morawa & 5 & 5 \\
\hline 3 & PPK Percut Sei Tuan & 5 & 5 \\
\hline 4. & KPU Kab. Deli Serdang & 15 & 15 \\
\hline Total & 30 & 25 \\
\hline
\end{tabular}

Sumber: Hasil Olahan, 2020

Jumlah populasi dalam penelitian sebanyak 30 orang yang berasal dari daerah yang mengalami keterlambatan pada rekapitulasi penghitungan suara di Kabupaten Deli Serdang pada penyelenggaraan Pemilu tahun 2019. Sedangkan sampel sebanyak 25 orang atau responden dengan perincian PPK/PSS di Kecamatan Tanjung Morawa mewakili daerah perkotaan, PPK/PSS di Kecamatan Percut Sei Tuan yang mewakili daerah pedesaan dan Komisioner/ Sekretariat KPU Kabupaten Deli Serdang yang mewakili daerah induk. 25 orang tersebut proporsional dalam hal mewakili keragaman data dan bisa menggambarkan populasi secara umum.

Teknik pengumpulan data dengan mengggunakan penyebaran kuisioner yang berisi daftar pertanyaan tertutup kepada responden. Masing-masing responden akan diberi daftar pertanyaan yang sama melalui kuisioner dalam rangka mengukur variabel (Neuman, 2003) serta berfungsi juga merekam jawaban responden (Sekaran, 1992). Jawaban responden kemudian diukur dengan memakai skala likert melalui gradasi yaitu :

Tabel. 4. Pemberian Skor Jawaban

\begin{tabular}{lll}
\hline SR & Selalu & Skor 5 \\
\hline SL & Sering & Skor 4 \\
\hline KD & Kadang-kadang & Skor 3 \\
\hline P & Pernah & Skor 2 \\
\hline TP & Tidak Pernah & Skor 1 \\
\hline \multicolumn{2}{c}{ Sumber: hasil olahan 2020}
\end{tabular}

Data bersumber dari 2 aaspek yakni pokok berupa kuisioner yang disebar untuk Responden, kemudian sumber tambahan berupa kajian pustaka, jurnal, disertasi, tesis, buku, majalah, arsip surat, dokumen rapat pleno yang berkaitan dengan topik penelitian.

Dalam peneltian kuantitatif diperlukan ketegasan defenisi operasional yang diambil dari teori. Dalam penelitian berdasarkan teori atau konsep yang relevan sesuai permasalahan diteliti untuk selanjutnya dirumuskan defenisi operasional serta variabel penelitian sebagaimana terdapat pada tabel 5 . 
Dana Permana, M. Arif Nasution \& Arifin Saleh Siregar, Analisis Faktor-Faktor Yang Mempengaruhi

\begin{tabular}{|c|c|c|c|}
\hline No & Variabel \& Indikator & Defenisi Operasional & Skala \\
\hline \multirow[t]{5}{*}{1.} & Integritas (X1) & $\begin{array}{l}\text { kualitas menjujung tinggi kejujuran dengan memegang teguh } \\
\text { prinsip-prinsip moral. }\end{array}$ & \\
\hline & $\begin{array}{l}\text { Terbuka } \quad \text { Terhadap } \\
\text { Tugas yang dikerjakan }\end{array}$ & $\begin{array}{l}\text { Transparan terhadap proses penghitungan suara kepada } \\
\text { peserta pemilu }\end{array}$ & \\
\hline & $\begin{array}{l}\text { Melakukan tugas tanpa } \\
\text { intervensi. }\end{array}$ & $\begin{array}{l}\text { Melaksanakan Rekap penghitungan tanpa ada pengaruh dari } \\
\text { pihak lain. }\end{array}$ & \\
\hline & $\begin{array}{l}\text { Tidak Membedakan } \\
\text { peserta Pemilu }\end{array}$ & $\begin{array}{l}\text { Memperlakukan sama setiap peserta pemilu dan dalam } \\
\text { mengkuti dan mengakses informasi penghitungan suara }\end{array}$ & \\
\hline & $\begin{array}{l}\text { Komitmen } \\
\text { Tugas }\end{array}$ & $\begin{array}{lccc}\begin{array}{l}\text { Keaktifan dalam } \\
\text { penghitungan suara }\end{array} & \text { menyelesaikan } & \text { proses } & \text { rekapitulasi } \\
\end{array}$ & \\
\hline \multirow[t]{3}{*}{2.} & Beban Kerja (X2) & $\begin{array}{l}\text { Pekerjaan yang musti disiapkan sebuah badan atau jabatan } \\
\text { dalam tempo yang sudah ditentukan. }\end{array}$ & \\
\hline & $\begin{array}{l}\text { Banyaknya Pekerjaan } \\
\text { yang disiapkan }\end{array}$ & Jumlah Tugas terkait penyelenggaraan Pemilu & \\
\hline & $\begin{array}{l}\text { Tingkat Kesulitan } \\
\text { menyelesaikan tugas }\end{array}$ & Tingkat ke & \\
\hline \multirow[t]{4}{*}{3.} & Kompetensi (X3) & $\begin{array}{l}\text { Kemampuan seseorang dalam menyelesaikan aneka ragam } \\
\text { kegiatan. }\end{array}$ & \\
\hline & Perencanaan & Kapabiltas dalam merencakan penyelesaian tugas kepemiluan & \\
\hline & Pengetahuan & Pemahaman kognitif terhadap Pemilu & \\
\hline & Pengalaman & Jam terbang dalam kegiatan kepemiluan & \\
\hline \multirow[t]{2}{*}{4.} & $\begin{array}{l}\text { Keterlambatan } \\
\text { Penghitungan Suara (Y }\end{array}$ & $\begin{array}{l}\text { Kegiatan Penghitungan Suara yang dilaksanakan tidak sesuai } \\
\text { Jadwal Pemilu }\end{array}$ & \\
\hline & Waktu & $\begin{array}{l}\text { Pelaksanaan Waktu rekapitulasi melebihi jadwal dalam Regulasi } \\
\text { KPU }\end{array}$ & \\
\hline
\end{tabular}

Sumber: Hasil Olahan 2020

Setelah data terkumpylam dari responden maupun sumber lainnya kemudian data tersebut diolah. Model analisis data dalam penelitian ini yakni proses analisis data terhadap data-data / angka-angka yang akan diolah melalui statistik dengan alat bantu SPSS dan sejenisnya menemukan korelasi memakai tehnik analisis regresi linear berganda.

Dilaksakanak untuk menguji apakah kuesioner cocok dan bisa dipakai sebagai instrumen penelitian. Dikatakan valid bila instrumen digunakan untuk mengukur apa yang seharusnya diukur. Dan dikatakan reliabel jika instrumen apabila dipakai lebih dari satu kali untuk menilai sasaran yang sama, akan menghasilkan data yang sama pula.

Dalam uji asumsi klasik dilaksanakan pengujian terhadap penyimpangan dari data yang sudah dikumpulkan. Dalam asumsi pengujian terdapat beberapa prosedur uji yang dilaksanakan yakni Uji Normalitas, Uji Multikolonieritas dan Uji Heterokedastisitas.

Uji statistik menggunakan analisis regresi linier berganda yakni analisis yang digunakan untuk menyajikan data dalam bentuk angka. Data pada penelitian ini merupakan data ordinal dengan persamaan:

$[\mathrm{Y}=\mathrm{bo}+\mathrm{b} 1 \mathrm{X} 1+\mathrm{b} 2 \mathrm{X} 2+\mathrm{b} 3 \mathrm{X} 3+\mathrm{e}]$

Dimana:

$\mathrm{Y}=$ Keterlambatan Rekapitulasi

$\mathrm{X} 1=$ Integritas

$\mathrm{X} 2=$ Beban Kerja

$\mathrm{X} 3=$ Kompetensi

bo $=$ Konstanta

b1 - b3 = Koefisien Regresi

e $=$ Standart error (tingkat kesalahan) yaitu $0,05(95 \%)$

Uji Hipotesis, Uji Parsial (Uji t), Dilakukan dalam rangka menguji pengaruh yang bersifat parsial antara variabel independen terhadap variabel dependen dengan memakai asumsi bahwa variabel lain dianggap konstan, Uji Simultan (Uji f), Dimaksudkan untuk menguji apakah secara simultan variabel independen berpengaruh terhadap variabel dependen.

H0 diterima jika Fhitung < Ftabel maknanya apabila nilai Fhitung lebih kecil dari pada Fttabel, berarti Fhitung berada di daerah penerimaan $\mathrm{H} 0$, kesimpulannya variabel bebas 
secara bersama-sama tidak punya pengaruh terhadap variabel terikat.

HO ditolak (Ha diterima) jika Fhitung > Ftabel), artinya jika nilai F.hitung lebih besar dari pada Ftabel, berarti $F$ hitung berada di daerah penerimaan $\mathrm{Ha}$, maknanya variabel bebas punya pengaruh bersama-sama kepada variabel terikat.

Koefisien

Determinasi

$\left(\mathrm{R}^{2}\right)$,

memperlihatkan seberapa besar kemampuan varians atau sebaran dari variabel independen menjelaskan variabel dependen atau bisa dikatakan dalam bentukan angka yang memberikan makna seberapa besar variabel dependen dipengaruhi oleh variabel independennya dengan rumus : $\mathrm{D}=\mathrm{r} 2 \times 100 \%$, Dimana : D : Koefisien Determinasi dan $r$ : Koefisien variabel bebas dan variabel terikat.

\section{HASIL DAN PEMBAHASAN \\ Pengaruh Integritas Penyelenggara \\ Terhadap Keterlambatan Rekap \\ Penghitungan Suara}

Hasil pengujian statistik menunjukkan bahwa secara parsial memiliki nilai $t_{\text {hitung }}-3,059$ lebih kecil dari nilai $t_{\text {tabel }}$ 2,079 dengan nilai signifikansi 0,006 >0,05. Maka $\mathrm{H}_{0}$ diterima dan $\mathrm{H}_{1}$ ditolak. Sehingga kesimpulannya secara parsial Variabel Integritas Penyelenggara (X1) tidak berpengaruh langsung terhadap terjadinya keterlambatan Rekapitulasi penghitungan suara (Y) di Kabupaten Deli Serdang.

Hal ini menguatkan bahwa secara empiris, penyelenggara Pemilu baik ditingkat KPU Kabupaten Deli Serdang maupun penyelenggara di tingkat Kecamatan (PPK) mampu menjaga integritasnya sebagai penyelenggara Pemilu pada pelaksanaan rekapitulasi penghitungan suara pada Pemilu 2019 yang lalu.

Sejalan dengan temuan diatas, hal ini juga dapat di lihat bahwa sampai saat tidak ada kasus pelanggaran kode etik di Tim Pemeriksa Daerah Dewan Kehormatan Penyelenggara Pemilu tingkat Provinsi Sumatera Utara yang dilakukan oleh KPU dan jajarannya dalam hal rekapitulasi penghitungan suara.

Penjelasan diatas sebagaimana ditegaskan oleh ketua KPU Kabupaten Deli Serdang, Syahrial Efendi bahwa demi menjaga integritas penyelenggara Pemilu yang adil, transparan dan jujur maka ditekankan kepada seluruh penyelenggara Pemilu baik ditingkat KPU Kabupaten Deli Serdang, PPK, PPS hingga KPPS untuk menjaga integritas sebagai penyelenggara Pemilu secara melekat serta diikuti dengan penandatanganan pakta integritas oleh setiap penyelenggara pemilu.

\section{Pengaruh Beban Kerja Terhadap \\ Keterlambatan Rekap Penghitungan Suara}

Hasil pengujian statistic menunjukkan bahwa variabel Beban Kerja (X2) memiliki nilai $t_{\text {hitung }}$ 0,789 lebih kecil < dari nilai $t_{\text {tabel }} 2,079$ dengan nilai signifikansi $0,439>0,05$. Maka $\mathrm{H}_{0}$ diterima dan $\mathrm{H}_{1}$ ditolak. Sehingga kesimpulannya secara parsial Variabel Beban Kerja (X2) tidak berpengaruh langsung terhadap terjadinya keterlambatan Rekapitulasi penghitungan suara (Y) di Kabupaten Deli Serdang.

Hasil pengujian ini membuktikan bahwa dalam penyelenggaraan rekapitulasi penghitungan suara di Kabupaten Deli Serdang khususnya keterlambatan di Kecamatan Percut Sei Tuan dan Kecamatan Tanjung Morawa tidak kaitannya dengan beban kerja baik dalam dimensi banyaknya pekerjaan yang harus disiapkan ataupun dalam dimensi kompleksitas pekerjaan yang dikerjakan dalam kaitannya dengan penyelenggaraan rekapitulasi penghitungan suara di masing-masing Kecamatan.

Temuan ini juga menguatkan penelitian yang dilakukan oleh Primasari dan kawankawan (2019) yang melakukan penelitian untuk mengukur kekampuan auditor dalam mendeteksi kemungkinan adanya manipulasi dalam bidang keuangan dengan menggunakan beberapa variabel seperti beban kerja, tenggat waktu dan supervisi. Dalam temuan tersebut disimpulkan bahwa variabel beban kerja dan tenggat waktu tidak berpengaruh terhadap kemampuan auditor dalam mendeteksi manipulasi.

\section{Pengaruh Kompetensi Penyelenggara Terhadap Keterlambatan Rekap Penghitungan Suara}

Hasil pengujian statistik menunjukkan Variabel Kompetensi Penyelenggara (X3) memiliki nilai $t_{\text {hitung }} 2,465$ lebih besar $>$ dari nilai $t_{\text {tabel }}$ 2,079 dengan nilai signifikansi 0,022 $<0,05$. Maka $\mathrm{H}_{0}$ ditolah dan $\mathrm{H}_{1}$ diterima. Sehingga kesimpulannya secara parsial 
Variabel Variabel Kompetensi Penyelenggara (X3) berpengaruh langsung terhadap terjadinya keterlambatan Rekapitulasi penghitungan suara (Y) di Kabupaten Deli Serdang.

Hal ini membuktikan bahwa dalam penyelenggaraan pemilu 2019 yang lalu kompetensi penyelenggara memiliki pengaruh terhadap pelaksanaan pemilu tahun 2019 di Kabupaten Deli Serdang. Kompetensi diukur melalui indikator dalam penelitian terdiri dari 3 dimensi yakni perencanaan, pengetahuan dan pengalaman, yang kemudian merujuk hasil uji validitas dan reliabilitas dikerucutan menjadi hanya 2 indikator dengan menghilangkan indikator pengalaman.

Merujuk pada tabulasi jawaban responden terkait indikator yang diukur yakni perencanaan dan pengatahuan diketahui bahwa sebaran jawaban responden tersebar 50 $\%$ menjawab pilihan nilai 5 dan 4 dan $50 \%$ lagi memilih menjawab pilihan nilai 1,2 dan 3 .

Jika dilihat dari data yang ada bahwa dalam kompetensi jika dikaji dari segi penyelenggara bahwa dalam pelaksanaan Pemilu 2019 yang lalu, personil penyelenggara Pemilu Kabupaten Deli Serdang merupakan wajah-wajah baru yang secara pengalaman baru pertama melaksanakan even Pemilu.

Dalam konteks KPU Kabupaten Deli Serdang sendiri baru saja dilaksanakan rekruitmen komisioner baru dimana dari 5 komisioner yang ada, 4 diantaranya merupakan wajah baru sedangkan 1 lainnya merupakan incumbent yang tidak lain adalah mantan Ketua KPU Kabupaten Deli Serdang. Meski unsur secretariat ASN KPU di kantor KPU Kabupaten Deli Serdang adalah mereka berpengalaman namun dalam konteks pekerjaan sekretariat berfungsi sebagai fasilitator sedangkan untuk kebijakan berada di ranah komisioner.

Begitu juga di level PPK di Kecamatan Percut Sei Tuan dan Kecamatan Tanjung Morawa merupakan wajah baru meskipun beberapa memiliki pengalaman sebagai penyelenggara Pemilu di tingkat PPS.

Secara empirik merujuk pada beberapa penelitian sebelumnya bahwa kompetensi berkaitan erat dengan SDM dan pencapaian organisasi. Temuan dalam penelitian ini senanda dengan penelitian Sirajudin dan Oktaviani (2018) yang meneliti apakah ada pengaruh antara kompetensi dengan kualitas audit. Dengan kesimpulan bahwa variabel kompetensi berpengaruh signifikan terhadap kualitas audit. Sama halnya dengan kajian Mottoh (2014) yang menganalisis bahwa pengaruh kompetensi SDM erat kaitannya dengan kegagalan melaksanakan kegiatan pemutakhiran data pemilih di KPU Kabupaten Minahasa. Sedang dalam konteks ini terjadinya keterlambatan rekapitulasi penghitungan suara di KPU Kabupaten Deli Serdang turut dipengaruhi oleh permasalahan kompetensi SDM penyelenggara pemilu.

\section{SIMPULAN}

Dari hasil penelitian yang penulis lakukan untuk melihat peristiwa keterlambatan rekapitulasi penghitungan suara di Kabupaten Deli Serdang pada Pemilu 2019 yang lalu. Penulis menggunakan asumsi untuk menguji bahwa keterlambatan tersebut disebabkan oleh 3 faktor yakni faktor integritas penyelenggara pemilu, faktor beban kerja dan faktor kompetensi penyelenggara pemilu. Dimana masing-masing faktor tersebut diistilahkan sebagai variabel independen (bebas) dengan simbol X1,X 2 dan X3 terhadap peristiwa keterlambatan rekapitulasi penghitungan suara di Kabupaten Deli Serdang pada Pemilu 2019 sebagai variabel dependen (tergantung) dengan simbol Y. Variabel integritas penyelenggara pemilu, faktor beban kerja dan faktor kompetensi penyelenggara pemilu secara simultan (bersama-sama) berpengaruh terhadap keterlambatan rekapitulasi penghitungan suara di Kabupaten Deli Serdang pada Pemilu 2019 sebesar 35,8\% sedangkan sisanya $64,2 \%$ disebabkan variabel lain yang tidak diteliti di tesis ini. Sehingga Dugaan 1 (H1) dimana H1 diterima dan H0 ditolak. Variabel integritas penyelenggara pemilu secara sendiri tidak memiliki pengaruh langsung kepada keterlambatan rekapitulasi penghitungan suara di Kabupaten Deli Serdang pada Pemilu 2019. Melalui hasil uji t dimana nilai thitung $-3,059$ lebih kecil dari nilai ttabel 2,079 dengan nilai signifikansi 0,006 >0,05. Maka H0 diterima dan $\mathrm{H} 1$ ditolak. Variabel beban kerja secara parsial tidak memiliki pengaruh langsung kepada keterlambatan rekapitulasi penghitungan suara di Kabupaten Deli Serdang pada Pemilu 2019. Melalui hasil uji t dimana memiliki nilai thitung 0,789 lebih kecil < dari nilai ttabel 2,079 dengan nilai signifikansi 0,439>0,05. Maka H0 diterima dan H1 ditolak. Variabel kompetensi penyelenggara pemilu secara parsial berpengaruh langsung 
terhadap keterlambatan rekapitulasi penghitungan suara di Kabupaten Deli Serdang pada Pemilu 2019. Melalui hasil uji t dimana. Nilai thitung 2,465 lebih besar $>$ dari nilai ttabel 2,079 dengan nilai signifikansi 0,022 $<0,05$. Maka H0 ditolak dan H1 diterima.

\section{DAFTAR PUSTAKA}

Birch, S. (2011). Post-Soviet Electoral Practices in Comparative Perspective. Europe-Asia Studies, 63(4), 703-725.

BPS Deli Serdang, (2019), Laporan Sensus Penduduk Tahun 2019, Deli Serdang : BPS

Fatah, E.S., (1997), Evaluasi Pemilu Orde Baru,Jakarta: Mizan.

Gaffar, A, (2000), Politik Indonesia Transisi Menuju Demokrasi, Yogya: Pustaka Pelajar

Ham, C. v. (2015). Getting elections right? Measuring Electoral Integrity. Democratization, 22(4), 714-737.

Haris, S, (1998), Menggugat Pemilu Orde Baru, Jakarta: Yayasan Buku Obor.

International IDEA, (2005), Desain Sistem Pemilu, Swedia : IDEA

International IDEA, (2016), Annual Resort Report 2016, Swedia : IDEA

KPU Deli Sedang, (2019), Laporan Pelaksanaan Pemilu Tahun 2019, Deli Serdang : KPU Kabupaten Deli Serdang

Lisa, H., (2007), Political Reseacrh: An Introduction (terj), Jakarta: Kencana

Lisa, H., (2007), Political Reseacrh: An Introduction (terj), Jakarta: Kencana.

Magridis, R.C. dan Huliung, M., (1997), Contemporary Political Idiologies: Pearson).

Magridis, R.C., dan Huliung, M., (1997), contemporary political idiologies: Pearson

Masmulyadi, (2019), Perihal Pemungutan dan Penghitungan Suara: Serial Evaluasi Pemilu 2019, Jakarta : Bawaslu.

Masmulyadi, (2019), Perihal Pemungutan dan Penghitungan Suara: Serial Evaluasi Pemilu 2019, Jakarta : Bawaslu., Hal.4).

Mottoh, E.M., (2014), Kinerja Komisi Pemilihan Umum Minahasa Selatan Dalam Pelaksanaan Pemilu Legislatif Tahun 2014 (skripsi)., Fisip Universitas Samratulangi.

Nasution, H., \& Fitriany. (2012). Pengaruh Beban Kerja, Pengalaman Audit dan Tipe Kepribadian terhadap Skeptisme Profesional dan Kemampuan Auditor dalam Mendeteksi Kecurangan. Jurnal Prosiding SNA XV.

Nasution, S., (1996), Metodologi Research Penelitian Ilmiah. Jakarta: Bumi Aksara

Norris, P., \& Grrmping, M. (2017). Populist Threats to Electoral Integrity: The Year in Elections,
2016-2017. SSRN Electronic Journal, 2016-

2017.

Ssrn.2965729.

https://doi.org/10.2139/

Norris, P., Frank, R. W., \& Martínez, F. (2014) Measuring Electoral Integrity around the World: A New Dataset. Political Science \& Politics, 47(4), 789-798.

Primasari, A., (2019), Pengaruh Independensi, Audit Tenure, Beban Kerja dan Tekanan Waktu Terhadap Kemampuan Auditor dalam Mendeteksi Kecurangan dengan Variabel Moderasi Pemahaman Kondisi Entitas dan Supervisi., Jurnal Inovasi Manajemen Ekonomi Akuntansi Vol 1 (1).

Strategies of Actors Influencing Electoral Integrity: A Case Study of the Czech Republic. Politologický časopis - Czech Journal of Political Science- XXIV/2017,249-274.

\section{Situs Internet}

http//:www.e- psikologi.com

http://www.elisamortiz.org/2011/01/7-skills-forsupervision-success/

https://hariansib.com/Medan-

Sekitarnya/Partisipasi-Pemilih-pada-

Pemilu-di-Deliserdang-73-34---dari-1-3-

Juta-DPT

https://hrdailyadvisor.blr.com/2009/06/21/sudd enly-a-supervisor-5-critical-factors-forsuccess/

https://id.wikipedia.org/wiki/Kabupaten_Deli_Ser dang

https://kabar24.bisnis.com/read/20190417/15/9 13023/dpr-peninjau-asing-apresiasi-pemiluserentak-tapi-damai

https://mediaindonesia.com/read/detail/230718komnas-ham-apresiasi-pelaksanaanpemilu.Eksekutif dan legislatif memberikan apresiasi yang positif terhadap pelaksanaan pemilu 2019

https://nasional.kompas.com/read/2019/04/24/1 1252091/wiranto-pelaksanaan-pemilu2019-dapat-banyak-apresiasi-dari-luarnegeri.

https://news.detik.com/berita/d-4556813/tersisa4-provinsi-kpu-lanjutkan rekapitulasinasional-pemilu-2019.

https://www.oxfordlearnersdictionaries.com/defin ition/english/integrity?q=integry

https://www.pinterpolitik.com/jokowi-apresiasipemilu-2019/https://infojambi.com/dpd-riapresiasi-pemilu-2019-berjalan-aman-dandamai/,

Kompas/ 19 Mei 2019

Medan Bisnis/19 Mei 2019 